ROCZNIKI TEOLOGICZNE

Tom LXVIII, zeszyt 9 - 2021

DOI: https://doi.org/10.18290/rt.21689.7

ZDZISŁAW KUPISIŃSKI SVD

\title{
ŚWIĘTY JÓZEF W RELIGIJNOŚCI I TRADYCJI LUDOWEJ W POLSCE
}

\author{
SAINT JOSEPH IN RELIGIOUSNESS AND FOLK TRADITION IN POLAND
}

A b s t r a c t. The veneration of the saints is, in its essence, worship of the One God and glorification of Him in the works He has done in His saints. It is also a way to express gratitude to God for allowing people to share in His holiness and bringing His chosen ones to the glory of heaven. One of the saints receiving special veneration in the Church is St. Joseph, the husband of Mary and the guardian of Jesus. The aim of this article is to present St Joseph on the basis of the Gospel narratives and to characterize the development of his cult in the Church, as well as in religiousness and popular tradition. While exploring the topic of the paper, the author drew upon theological and ethnological literature as well as his own ethnographic field research conducted in the Opoczno and Radom sub-regions (central Poland).

The cult of St Joseph can be seen not only in the Church liturgy, where his main feasts are celebrated on $19^{\text {th }}$ of March and $1^{\text {st }}$ of May, but also in folk religiosity. The veneration of St. Joseph is manifested in devotions in his honor, songs, prayers, numerous paintings with his image placed in houses and roadside shrines. St Joseph is often chosen as a patron of churches, towns, professions, and he is also considered the patron of the fathers and a guardian of a good death. His veneration is still vivid nowadays and many people obtain graces through his intercession.

Keywords: St. Joseph; veneration of saints; piety; popular religiosity; tradition.

Kult świętych bierze swój początek w tradycji oddawania czci zmarłym. Pierwsi chrześcijanie grzebali zmarłych na cmentarzach podziemnych (katakumby) lub naziemnych. W rocznicę urodzin osoby zmarłej rodzina zbierała

Dr hab. ZDZISŁAW KUPISIŃSKI SVD - Katedra Religiologii i Misjologii w Instytucie Nauk Teologicznych Katolickiego Uniwersytetu Lubelskiego Jana Pawła II, Al. Racławickie 14, 20-950 Lublin; e-mail: dzidek@kul.lublin.pl; ORCID: https://orcid.org/0000-0003-4775-278X. 
się przy grobie, przynosiła pokarmy i organizowała swego rodzaju ucztę. Miesiąc luty poświęcony był szczególnej pamięci o zmarłych, wówczas składano im najwięcej pokarmów. Początkowo chrześcijanie praktykowali niektóre dawne zwyczaje, unikając tych, które sprzeciwiałyby się wierze w zmartwychwstanie człowieka. Na cmentarzach sprawowano Eucharystię, ale rezygnowano z rytualnego płaczu i lamentacji, zastępując je śpiewem psalmów. Dzień śmierci stał się dla chrześcijan dniem narodzin dla nieba. Jako pierwszych z kandydatów do świętości chrześcijanie czcili męczenników, a więc tych, którzy swym życiem zaświadczyli o Chrystusie. Po zakończeniu okresu prześladowań, w Kościele pojawiła się asceza, czyli sposób życia, który zaczęto uważać za nową „drogę” prowadzącą do osiągnięcia świętości, jej szczytową realizacja miało być ofiarowanie dla Boga dziewictwa ${ }^{1}$.

Kult świętych w polskiej religijności ludowej jest zjawiskiem powszechnym. Na świętych patrzono jako na wzór moralny, godny naśladowania, bowiem dzięki życiu zgodnemu z nauką Chrystusa święci otrzymali nagrodę - osiągnęli niebo. Wierni częstokroć zwracali się do nich, by swym wstawiennictwem wypraszali u Boga potrzebne łaski. Dla ludzi wierzących święci stanowią społeczność zbawionych, do których w modlitwie można się zwracać, komunikować z nimi, a przez to liczyć na pomoc w trudnej sytuacji życiowej. Wśród świętych patronów wyróżnia się: opiekunów określonych terytoriów (kontynentów, krajów, archidiecezji, diecezji, miejscowości i parafii), zgromadzeń zakonnych, a także różnych stanów (np. panien, ojców i młodzieńców, matek i babć), zawodów (np. kolejarzy, rolników, górników, rybaków etc.) $)^{2}$.

Spośród świętych, którzy w Kościele odegrali znaczącą rolę, wyróżnia się wybrany na Opiekuna Zbawiciela - Józef z Nazaretu. Przedmiotem poniższego artykułu będzie ukazanie postaci św. Józefa - Oblubieńca Najświętszej Maryi Panny, i prezentacja jego kultu w Kościele powszechnym oraz w religijności ludowej na terenie Polski. Do opracowania tego zagadnienia skłonił autora list apostolski papieża Franciszka Patris $\operatorname{Corde}^{3}$ napisany z okazji 150. rocznicy

${ }^{1}$ Bogusław Nadolski, Liturgika, t. 2: Liturgia i czas (Poznań: Pallottinum, 1991), 160 i 168 .

${ }^{2}$ Rajmund Jodko, „Święci i błogosławieni w pobożności ludowej”, w Liturgia i pobożność ludowa, red. Władysław Nowak (Olsztyn: Wydawnictwo Uniwersytetu Warmińsko-Mazurskiego, 2003), 212-215; Dorota Świtała-Trybek, Święta i zabawa. Odpusty parafialne na Górnym Ślasku (Wrocław: Polskie Towarzystwo Ludoznawcze, 2000), 22-23.

${ }^{3}$ Franciszek, List apostolski papieża Franciszka Patris Corde z okazji 150. rocznicy ogłoszenia świętego Józefa patronem Kościoła powszechnego, Biuletyn Tygodniowy CIZ 8-14 grudnia 2020, 50 (2020) (617): 8-13, dostęp 03.02.2021, https://ekai.pl/dokumenty/list-apostolski-patris-corde-ojca-swietego-franciszka-z-okazji-150-rocznicy-ogloszenia-swietego-jozefa-patro 
ogłoszenia świętego Józefa patronem Kościoła powszechnego oraz obranie go za patrona roku liturgicznego 2021, co zostało ogłoszone w Uroczystość Niepokalanego Poczęcia Najświętszej Maryi Panny, w ósmym roku Pontyfikatu Franciszka. Autor, ukazując sylwetkę św. Józefa, przyjmuje inną niż dotychczasowe opracowania perspektywę - koncentruje się nie na teologicznych rozprawach dotyczących tej postaci, ale na jej kulcie w religijności i tradycji ludowej. Nie ma bowiem we współczesnych publikacjach opracowań, które łączyłyby te dwa aspekty przedstawiające znaczenie św. Józefa w Kościele oraz w religijności i obrzędowości ludowej. O jego żywym kulcie występującym wśród wiernych do dziś świadczy fakt, że uważany jest za wspomożyciela rodzin, ojców, kobiet w ciąży, robotników, nauczycieli, misjonarzy, wygnańców i deportowanych oraz ludzi umierających - jako patron dobrej śmierci. Jest patronem Kościoła powszechnego, obu Ameryk, wielu krajów - Meksyku (od 1555 r.), Kanady (od 1624 r.), Peru (od 1655 r.), Belgii (od 1679 r.), regionów, miast (np. Krakowa od 1714 r.) i diecezji ${ }^{4}$.

W opracowaniu tego zagadnienia autor korzystał z własnych etnograficznych badań terenowych prowadzonych w subregionach opoczyńskim i radomskim w latach 1990-1993, 1995-2005 oraz z literatury przedmiotu, odwołując się nie tylko do publikacji stricte teologicznych, przedstawiających św. Józefa oraz jego miejsce i znaczenie w Kościele powszechnym, ale również do literatury religioznawczej ukazującej tę postać w religijności i tradycji ludowej na terenie Polski. Artykuł składa się z dwóch paragrafów. W pierwszym zostanie przedstawiona postać i znaczenie św. Józefa w Kościele powszechnym, a w drugim kult tego świętego w religijności i tradycji ludowej.

\section{POSTAĆ ŚW. JÓZEFA W KOŚCIELE POWSZECHNYM}

Pewnych informacji o św. Józefie - Oblubieńcu Najświętszej Maryi Panny dostarczają nam Ewangelie. Apokryfy ${ }^{5}$, które zawierają więcej wiadomości na

nem-kosciola-powszechnego/http://www.vatican.va/content/francesco/pl/apost_letters/documents /papa-francesco-lettera-ap_20201208_patris-corde.html.

${ }^{4}$ Marzena Straszewicz, „Józef Oblubieniec, II. Kult”, w Encyklopedia katolicka, t. 8, red. Bogusław Migut i in. (Lublin: Towarzystwo Naukowe KUL, 2000), 126; Franciszek Marlewski, red., Rok Boży w liturgii i tradycji Kościoła świętego z uwzględnieniem obrzędów i zwyczajów ludowych oraz literatury polskiej. Księga ku pouczeniu i zbudowaniu wiernych katolików (Katowice: Wydawnictwo św. Stanisława 1931), 210-214.

${ }^{5}$ Apokryfy opisują rodzinę św. Józefa, jego małżeństwo, pracę i śmierć. O latach dzieciństwa i młodości niewiele możemy się z nich dowiedzieć. Pisma te przepełnia fantazja, więc 
temat tej postaci, nie moga być traktowane jako wiarygodne, a tym samym stanowić źródeł, na które można powoływać się w publikacjach naukowych. Ewangelie poświęcają św. Józefowi 26 wierszy, a jego imię wymieniają 14 razy. Ewangeliści Mateusz i Łukasz niewiele piszą o tym świętym, ale wystarczająco, by dostrzec, jakim był ojcem i jak wypełnił powierzoną mu przez Boga misję. Ewangelie przedstawiaja go jako człowieka sprawiedliwego, pobożnego, pracowitego, pokornego, ale i sprawnego w działaniu. Wzmianki o nim pojawiają się w pismach św. Hieronima i Augustyna, a naukę o jego cnotach rozwijali: św. Bernard z Clairvaux, Tomasz z Akwinu, Albert Wielki, Brygida Szwedzka, św. Teresa z Avila 6 .

Św. Józef pochodził z rodu Dawida z Betlejem. Był mężem Maryi w momencie poczęcia Jezusa za sprawą Ducha Świętego, a więc nie ojcem Chrystusa Pana według ciała, co potwierdzają ewangeliści (Mt 1,18.20; Łk 1,35). Natomiast ojcem pozostał według Prawa żydowskiego, gdyż był prawomocnym małżonkiem Maryi. W ósmym dniu, gdy obrzezał dziecko i nadał mu imię Jezus, według Prawa uznawany był za ojca (MT 1,25; Łk 2,21-39); był jego ziemskim opiekunem (Łk 2,41-50). Św. Józef razem z Maryją wychowywał Jezusa, uczył go modlitwy, żydowskiego Prawa, zawodu (Mk 6,3). Profesja, którą się trudnił, określana jest w Ewangelii za pomocą greckiego słowa tekton bądź hebrajskiego charasz, co oznaczałoby rzemieślnika wykonującego prace w drewnie, metalu, kamieniu, a zdaniem św. Justyna (ok. 100-ok. 166) św. Józef wykonywał sochy drewniane i jarzma na woły, czyli narzędzia gospodarcze i rolnicze. Gdy w Piśmie Świętym jest mowa o rozpoczęciu publicznej działalności Pana Jezusa jako Nauczyciela, nie pojawia się już żadna wzmianka na temat św. Józefa, co może sugerować, że wówczas już nie żył. Prawdopodobnie miał najpiękniejszy pogrzeb, gdyż w tych ostatnich chwilach życia byli przy nim Jezus i Maryja. Być może właśnie dlatego w tradycji obrano go za patrona dobrej śmierci ${ }^{7}$.

nie należy ich traktować jako wiarygodnych dokumentów. Oto niektóre z nich: Protoewangelia Jakuba (z II wieku), Ewangelia Pseudo-Mateusza (VI wiek), Ewangelia Narodzenia Maryi (IX wiek), Ewangelia Tomasza (II wiek) i Historia Józefa Cieśli (IV wiek). Zob. Wincenty Zaleski, Rok kościelny. Święta Pańskie, Matki Bożej, Apostołów, Świętych i Btogosławionych Pańskich oraz dni okolicznościowe (Warszawa: Wydawnictwo Salezjańskie, 1989), 170.

${ }^{6}$ Stefan Szymik, ,Józef Oblubieniec, I. Życie”, w Encyklopedia katolicka, t. 8, 124-125; Zaleski, Rok kościelny, 172; Wacław Piszczek CM, Wspomnienie świętych na każdy dzień. Martyrologium (Kraków: Wydawnictwo Instytutu Teologicznego Księży Misjonarzy, 2005), 77.

${ }^{7}$ Szymik, ,Józef Oblubieniec”, 124-125; Zaleski, Rok kościelny, 170-171; Francis L. Filas, Św. Józef człowiek Jezusowi najbliższy, tłum. Franciszek Dylewski (Kraków: Wydawnictwo WAM, 1979), 140-143; Piszczek, Wspomnienie świętych, 77. 
Początki kultu Józefa nie są znane, a jego domniemany grób w dolinie Jozafata czczono dopiero od VI wieku. Jego kult liturgiczny na Wschodzie występował już od VII wieku, a na Zachodzie od XII wieku. W IX i X wieku Grecy czcili Józefa w ostatnią niedzielę Adwentu lub w niedzielę w czasie oktawy Bożego Narodzenia. Od VII wieku w Kościele koptyjskim 20 lipca obchodzono pamiątkę śmierci Józefa. W Kościele zachodnim kult świętego w liturgii potwierdzają rękopisy pochodzące z IX wieku, odnoszą się one do benedyktyńskiego klasztoru na wyspie Reichenau (jezioro Bodeńskie w Niemczech), a od X wieku imię św. Józefa regularnie wymienia Martyrologia pod datą 19 marca. O tym święcie wspomina Jan Gerson w 1416 r. na soborze w Konstancji. W 1479 r. papież Sykstus IV wprowadził święto św. Józefa do brewiarza i mszału rzymskiego, a w 1621 r. papież Grzegorz XV rozszerzył je na cały Kościół. Papież Pius IX dekretem Quaemadmodum Deus z 10 września 1847 r. wprowadził odrębne święto liturgiczne Opieki św. Józefa i wyznaczył obchody tego święta na trzecią niedzielę po Wielkanocy i ogłosił Józefa patronem Kościoła powszechnego w 1870 r. Papież Pius X przeniósł je na drugą środę po Wielkanocy, podnosząc rangę święta do uroczystości, ale zmieniając jego nazwę na Świętego Józefa Oblubieńca Najświętszej Maryi Panny, Wyznawcy, Patrona Kościoła Powszechnego. Z kolei papież Pius XII zniósł to święto, ale na jego miejsce wprowadził w 1956 r. nowe, tej samej klasy: Święto Józefa Robotnika (1 maja), jednakże ranga święta została obniżona do drugiego stopnia, czyli do wspomnienia (1969). Tytuł Patrona Kościoła świętego Pius XII dołączył do uroczystości św. Józefa obchodzonej 19 marca ${ }^{8}$. Na przestrzeni wieków kult św. Józefa dostrzega się w modlitwach włączanych do liturgii i paraliturgii Kościoła. Papież Leon XIII wprowadził modlitwę do św. Józefa, którą odmawiano bezpośrednio po mszy św. (1884), a papież Benedykt XV dołączył do mszy św. prefację o św. Józefie (1919), natomiast papież Jan XXIII włączył imię św. Józefa do kanonu mszy św. (1961) 9 .

\footnotetext{
${ }^{8}$ Dekret o obchodzeniu święta św. Józefa w liturgii ogłosił papież Sykstus IV przed 1479 r., ustalając datę na 19 marca, a Grzegorz XV podniósł je w 1621 r. do rangi święta obowiązującego w całym Kościele. Natomiast papież Benedykt XV w 1920 r. zalecił poświęcać w liturgii cześć św. Józefowi w każdą środę roku i przez cały miesiąc marzec. Straszewicz, „Józef Oblubieniec”, 125-126. Papież Pius XII w miejsce obchodzonego wcześniej święta św. Józefa w środę po drugiej niedzieli Wielkanocy wprowadził nowe święto św. Józefa Robotnika (1 maja), ale ranga liturgiczna tego święta została obniżona do wspomnienia (1969). Zaleski, Rok kościelny, 173; Straszewicz, „Józef Oblubieniec”, 126; Jodko, „Święci i błogosławieni w pobożności ludowej”, 216.

${ }^{9}$ Zaleski, Rok kościelny, 173. Papież Benedykt XIII włączył imię św. Józefa do litanii Wszystkich Świętych (1726), a Benedykt XV wezwanie o św. Józefie do modlitw zaczynają-
} 
W ikonografii na ogół przedstawia się św. Józefa jako starca. Sztuka chrześcijańska zostawiła wiele wizerunków tego świętego w rzeźbie i malarstwie, jednakże zwykle występuje w scenach zbiorowych jako jedna z postaci Świętej Rodziny (Józef, Maryja i Jezus) ${ }^{10}$. Największe sanktuarium św. Józefa znajduje się w Kanadzie w Montrealu (1904), inne, w których są jego cudowne wizerunki, to katedra w Parmie (od 1074 r.) czy kościół św. Józefa w Bolonii (od 1129 r.) etc. Pierwszym kościołem na świecie, jaki powstał ku czci św. Józefa, jest bazylika w Nazarecie, wzniesiona przez krzyżowców w XII wieku, natomiast najstarszym w Europie jest kościół w Bolonii (1129) oraz w Alcester w Anglii (1140). Początki kultu świętego w Polsce przypadają na średniowiecze, jego rozkwit datuje się od XVII wieku i związany jest z powstaniem sanktuarium w Kaliszu. W Polsce kościoły pod wezwaniem św. Józefa pochodzą z XVII wieku, do najstarszych należy kościół Karmelitanek Bosych w Lublinie (1624), Bernardynek w Krakowie (1646) oraz Cystersów w Krzeszowie (1692). Kult św. Józefa szerzy się w Polsce między innymi wokół obrazu św. Józefa trzymającego Dzieciątko Jezus na rękach (autorstwa karmelity Łukasza od św. Karola - 1669), który znajduje się u Karmelitów Bosych w Krakowie. Inny obraz to św. Józef w gronie Najświętszej Rodziny z XVIII wieku, znajdujący się w kościele św. Michała w Kaliszu ${ }^{11}$.

O początkach kultu św. Józefa w Polsce dowiadujemy się z Benedykcjonału Wawelskiego pochodzącego z przełomu XI/XII wieku, gdzie pod data 19 marca jest mowa o święcie św. Józefa Żywiciela Pana ${ }^{12}$. Pomimo iż

cych się od słów: „Niech będzie Bóg uwielbiony”. Została też wydana pierwsza w dziejach Kościoła encyklika o św. Józefie Quamquam pluries (papież Leon XIII), a papież Pius X zatwierdził litanię do św. Józefa do publicznego odmawiania, zawiera ona wezwanie: „Święty Józefie Opiekunie Kościoła Świętego”. Tamże, 173; Straszewicz, „Józef Oblubieniec”, 126; Tadeusz Fitych, Trójca stworzona - nauka o św. Józefie na Ślasku (Lublin: Towarzystwo Naukowe KUL, 1990), 52-54.

${ }^{10}$ Zaleski, Rok kościelny, 172.

${ }^{11}$ Obecnie jest w Polsce około 250 kościołów parafialnych pod wezwaniem św. Józefa, w tym 60 - Józefa Oblubieńca NMP, 54 - Józefa Rzemieślnika (lub Robotnika), 1 - Opieki Józefa, 1 - Józefa Opiekuna Rodzin. Straszewska, „Józef Oblubieniec”, 126.

12 Zaleski, Rok kościelny, 175. O św. Józefie wspomina także bł. Władysław z Gielniowa $(† 1505)$, wskazując na jego zalety (Godzinki o Niepokalanym Poczęciu Maryi, Godzinki o św. Annie). Natomiast Piotr Skarga (†1612) w homilii na 19 marca pisał: „Między nimi jest św. Józef, oblubieniec i małżonek kwiata i czystości nigdy nie zwiędłej Panny Bogarodzicy, którego dziś Kościół wspomina, o którego żywocie pisma mało - ale tajemnic wiela. A kto z tym zrównać się może, który nad innych stał świata; któremu Bóg po Maryi wcielenie swoje i przyjście swoje w żywot Pański objawił i tę tajemnicę jemu przez anioła podał; który uczyniony jest stróżem wiernym czystości Matki Przenajświętszej, opiekuna ubogiego w ciele Boga, karmicielem Mesjasza, obrońcą sieroctwa, nosicielem dzieciństwa, wychowującym młodość Pana wszyst- 
chrześcijaństwo dopiero rozwijało się na terenie Polski, wierni dostrzegali już wielkość i znaczenie św. Józefa dla Świętej Rodziny z Nazaretu, a także dla całego Kościoła, dlatego obierali go za swego patrona. Cześć oddawana już wówczas temu świętemu wskazuje na pionierską postawę w rozpowszechnianiu jego kultu na terenie Europy. Jednak pełny kult św. Józefa na obszarze Polski przypada na wiek XVII i XVIII, propagowany był przede wszystkim przez siostry wizytki i karmelitów. W 1645 r. wydrukowano Godzinki ku jego czci, a w 1685 r. ukazała się pierwsza rozprawa teologiczna o św. Józefie napisana przez Jana Chryzostoma Rucieńskiego ${ }^{13}$.

W Polsce centrum kultu i nabożeństw do św. Józefa skupia się w Kaliszu. Na przełomie XVI i XVII wieku w Kolegiacie Kaliskiej pojawił się obraz św. Józefa nieznanego autora, stanowił on wotum wdzięczności chorego za uzdrowienie. Obraz przedstawia Świętą Rodzinę (Maryję pochyloną nad Jezusem i św. Józefa z lilią w ręku). Pomimo że na obrazie widnieje Święta Rodzina, to szczególnym kultem otaczany jest św. Józef. Od czasu ulokowania obrazu w Kolegiacie zaczęły się dziać liczne cuda, wierni doznawali rozmaitych łask za wstawiennictwem św. Józefa, pierwsza historyczna wzmianka o tym obrazie pochodzi z $1673 \mathrm{r}^{14}$

kiego świata? Komu tak wielkich rzeczy powierzono? Czyjej tak cnocie Pan Bóg zaufał i polecił rzeczy tak wielkie?". Cyt. za: Zaleski, Rok kościelny, 175.

13 Zaleski, Rok kościelny, 176. O wzroście zainteresowania na terenie Polski kultem św. Józefa świadczy także fakt, że w XVII wieku o tym świętym zanotowano 6 publikacji, a już w następnym, XVIII wieku, ukazało się ich 49. Tamże.

14 Twórca obrazu jest nieznany, ponieważ archiwalne dokumenty uległy zniszczeniu podczas pożarów i wojen. Znawcy sztuki malarskiej wskazują, że najprawdopodobniej namalował go Polak, na co wskazuje postać św. Józefa, gdyż jego rysy, a także Maryi i Jezusa są na wskroś typu polskiego. Źródła historyczne wskazują na tradycję, którą spisał ks. prałat Stanisław Józef Kłossowski, powołując się na informacje otrzymane od ks. kanonika Józefa Świtalskiego ( $† 1758)$ w dziele pod tytułem Cuda $i$ łaski za przyczyna $i$ wzywaniem mniemanego ojca Jezusowego, św. Józefa, przy obrazie tegoź świętego patriarchy w Kolegiacie kaliskiej (wydane w Kaliszu w 1788 r.). W książce nie podaje, kiedy powstał obraz, ale opisuje cuda, jakie się dokonały od 1673 r. Wskazywałoby to, że już wówczas obraz znajdował się w Kolegiacie Kaliskiej. Ks. Kłossowski opisuje w swej książce, że najwięcej cudów doznano podczas Powszechnego Jubileuszu, ogłoszonego przez papieża Benedykta XIV w roku 1751 (600 cudownych uzdrowień i łask). Zob. Zenon Kalinowski, „Święta Rodzina”, Nasza Rodzina nr 5 (320) (1971): 10-11, dostęp 01.02.2021, http://recogito.eu/swieta-rodzina/. W roku 1768 prymas Polski Władysław Aleksander Lubieński ogłosił, że obraz św. Józefa jest „słynący łaskami”. Papież Pius VI wydał dekret na koronację obrazu (1783), która odbyła się dopiero po rozbiorach Polski (15 maja 1796), dokonał jej sufragan gnieźnieński Michał Kossowski. W 1963 r. odbyło się nałożenie św. Józefowi pierścienia, ofiarowanego przez papieża Jana XXIII; podobny pierścień przekazał papież św. Pius X. Papież Paweł VI ofiarował dla kolegiaty ornat, w którym on jako pierwszy odprawiał mszę św. ku czci św. Józefa. Zob. Zalewski, Rok kościelny, 176. 
Sanktuarium w Kaliszu stało się centrum polskiego kultu św. Józefa ze względu na aspekty historyczne - tutaj gromadzili się wierni i doznawali wielu łask za przyczyną patrona, ale i dlatego, że w tym właśnie miejscu zaczęto gromadzić wszelką dokumentację związana z kultem św. Józefa. Ponadto do wyjątkowego rozwinięcia kultu św. Józefa Kaliskiego i jego znaczenia przyczyniły się takie wydarzenia, jak: cudowne wyzwolenie księży - więźniów z obozu Dachau, które nastąpiło 29 kwietnia 1945 (księża 22 kwietnia 1945 r. złożyli św. Józefowi śluby, że jeżeli odzyskają wolność, to co roku będą pielgrzymować do jego sanktuarium w Kaliszu), utworzenie w Kaliszu Polskiego Studium Józefologicznego (24 września 1969) oraz wizyta papieża Jana Pawła II w Kaliskim Sanktuarium (4 czerwca 1997) ${ }^{15}$. Wiele zgromadzeń zakonnych obierało sobie za patrona św. Józefa, m.in.: karmelici bosi, bazylianie, benedyktynki, salezjanie, józefitki, wizytki, felicjanki. Św. Józef jest głównym patronem diecezji włocławskiej, opiekunem wielu miast, miejscowości, a jego imię często nadawane jest dzieciom na chrzcie świętym.

\section{2. ŚWIĘTY JÓZEF W RELIGIJNOŚCI I TRADYCJI LUDOWEJ}

Dyrektorium o pobożności ludowej i liturgii mówi o harmonijnej zgodności między liturgią a pobożnością ludową. Przypomina zasady, które powinny być podstawą tej jedności, podaje wskazówki, jak Kościoły lokalne w działalności pastoralnej winny być otwarte na miejscową tradycję. Dyrektorium wiele uwagi poświęca św. Józefowi, zaznacza posłannictwo objawione mu od Boga o boskim pochodzeniu macierzyństwa Maryi (Mt 1,20-21) ${ }^{16}$.

Kult św. Józefa rozwinął się w pewnych formach folkloru oraz w nabożeństwach, m.in. w litaniach, pieśniach oraz różnych modlitwach (krótkich wezwaniach, różańcu, godzinkach). Wszystkie wspomniane formy modlitewne w pobożności ludowej wchodzą w skład różnych nabożeństw celebrowanych i odmawianych w celu uczczenia najważniejszych tajemnic z życia św. Józefa. Jak podkreśla nowe Dyrektorium, najbardziej znanym zwyczajem pocho-

\footnotetext{
15 Jacek Plota, „Sanktuarium św. Józefa w Kaliszu”, dostęp 02.02.2021, http://www.radosla w.home.pl/sanktuaria/kalisz.htm. Z innych sanktuariów św. Józefa w Polsce można wymienić: Niemysłów w diecezji włocławskiej, Raciąż Pomorski w diecezji chełmińskiej etc., z obrazów - wizerunek św. Józefa w kościele św. Jana w Toruniu. O popularności św. Józefa w Polsce świadczy m.in. fakt, że ku jego czci wystawiono ponad 320 kościołów. Zaleski, Rok kościelny, 176.

${ }^{16}$ Kongregacja ds. Kultu Bożego i Dyscypliny Sakramentów, Dyrektorium o pobożności ludowej $i$ liturgii. Zasady i wskazania, red. bp Stefan Cichy (Poznań: Pallottinum 2003), nr 218.
} 
dzącym z końca XVII wieku jest poświęcanie środy czci św. Józefa. Do tego zwyczaju nawiązuje celebrowane nabożeństwo „Siedem śród”. Ta cześć przejawia się również $\mathrm{w}$ licznych inwokacjach wyrażanych $\mathrm{w}$ formie modlitwy ułożonej przez papieża Leona XIII „Do Ciebie święty Józefie” czy w Litanii do św. Józefa zatwierdzonej przez papieża Piusa X, a także w nabożeństwie „Koronka do siedmiu lęków i siedmiu radości św. Józefa” (nr 222) ${ }^{17}$.

Przejawem kultu św. Józefa jako patrona kościoła czy zgromadzeń zakonnych są nabożeństwa odprawiane w poszczególnych dniach tygodnia czy miesiąca. Jak na przykład w Rudzie Śląskiej, gdzie św. Józef jest patronem tamtejszego kościoła, wierni poświęcają mu każdą pierwszą środę miesiąca. W tym dniu celebrowana jest uroczysta msza św., podczas której śpiewa się pieśni, wezwania i litanię do św. Józefa ${ }^{18}$. Pieśni i wezwania do św. Józefa wybrzmiewaja przede wszystkim 19 marca, kiedy to w Kościele obchodzona jest uroczystość Oblubieńca Najświętszej Maryi Panny oraz 1 maja - w święto św. Józefa Robotnika. Pieśni na stałe wpisały się w wyżej wymienione uroczystości i święta, wykonywane są wówczas na wszystkich mszach. $\mathrm{Na}$ Pomorzu rzemieślnicy zamawiali na 19 marca mszę św., prosząc Boga o błogosławieństwo w pracy (stolarze i cieśle) ${ }^{19}$. Z kolei w Jastarni „dzień 19 marca, czyli św. Józefa u rybaków nadmorskich i gospodarzy ma znaczenie szczególne. [...] jest to święto patronalne, na które rybacy zamawiaja mszę św. i śpiewaja po nabożeństwie suplikacje na dobry połów"20.

O wielkim szacunku i miłości do św. Józefa świadczy umieszczanie jego wizerunków $\mathrm{w}$ mieszkaniach oraz $\mathrm{w}$ kapliczkach występujących na terenie całego kraju. W Małopolsce figury św. Józefa sytuowano na czworobocznych słupach i kolumnach, a płaskorzeźby - na trzonach kamiennych kapliczek i krzyży. W Bożewie koło Sierpca drewniana neogotycka figurka ustawiona została na ceglanej kolumnie, a w innej podsierpeckiej wsi pomnik świętego

17 Dyrektorium o pobożności ludowej, 158; Zaleski, Rok kościelny, 172; Jodko, „Święci i błogosławieni”, 217.

18 Zob. Świtała-Trybek, Święto i zabawa, 33. Litanię dla całego Kościoła zatwierdzono 18 marca 1909 r., składają się na nią trzy części: pierwsza przedstawia godność św. Józefa, druga - jego przymioty, a trzecia - jego znaczenie dla wierzących i Kościół. Nabożeństwa diecezji katowickiej. Agenda liturgiczna (Katowice: Księgarnia św. Jacka, 1995), 528.

19 Jan Perszon, Na Jastra. Wielki Post i okres wielkanocny w Wejherowskiem (Luzino: Pektor, 1992), 12; tenże, Zwyczaje, obrzedy $i$ wierzenia doroczne $w$ regionie wejherowskim (Lublin: mps KUL, 1990), 98.

${ }^{20}$ Bożena Stelmachowska, Rok obrzęowy na Pomorzu (Toruń: Wydawnictwa Instytutu Bałtyckiego, 1933), 116. 
stoi na czworobocznym cokole zdobionym $\mathrm{z}$ trzech stron wizerunkami papieży: Piusa IX, Leona XIII, Piusa $X^{21}$.

W dekanacie gorzowskim (diecezja opolska) w uroczystym dniu św. Józefa nie można było wykonywać żadnych prac związanych z drewnem, by nie obrażać patrona cieśli i stolarzy. Tego dnia powstrzymywano się także od pójścia do lasu, gdyż istniało przekonanie, że może to wywołać nieszczęście ${ }^{22}$.

Pomimo że dzień św. Józefa przypada na czas postu, jeszcze w połowie minionego wieku nawet w kościołach zawierano w tym dniu małżeństwa (zwykle nowożeńcami były osoby starsze, wdowy lub wdowcy). Na ogół śluby odbywały się wówczas bez wesela, z małym rodzinnym przyjęciem, były skromne. Solenizanci świętujący tego dnia mieli świadomość, iż w uroczystość ich patrona Kościół udziela dyspensy na spożywanie pokarmów mięsnych. Stanowi to wyjątek, gdyż jeszcze do lat 60. ubiegłego wieku w niektórych rodzinach powstrzymywano się od nabiału i potraw mięsnych od Środy Popielcowej do Wielkanocy, przez cały czterdziestodniowy okres postu ${ }^{23}$.

W pobożności ludowej św. Józef uznawany był za patrona dobrej śmierci, gdyż według tradycji zmarł w spokoju i bez cierpienia. Chcąc wyprosić sobie szczęśliwą śmierć, zwracano się do niego na Kaszubach w następujący sposób:

Św. Józefie umierających obrońco, ja ciebie przy obecności Jezusa w przenajświętszym Sakramencie zostającego i przy oblubienicy twojej Panny najś. Maryi za patrona na dobrą śmierć obieram i mocno stanowię nigdy cię nie zapominać. $\mathrm{Amen}^{24}$.

lub:

Św. Józefie, w ręce twoje oddaję duszę moją, któremiś sobie zaślubił Pannę najś. Maryję, a potem niebieskiego piastował Jezusa, jako oni przytomni twojej śmierci byli, tak ty mojej śmierci racz być przytomny i ratuj mnie pomocą twoją. Amen.

W Opoczyńskiem m.in. odmawiano Litanię do świętego Józefa:

Kyrie elejson, Chryste elejson, Kyrie elejson.

Chryste usłysz nas, Chryste wysłuchaj nas.

Ojcze z nieba Boże, zmiłuj się nad nami.

${ }^{21}$ Tomasz Czerwiński, Kapliczki i krzyże przydrożne w Polsce (Warszawa: Sport i Turystyka Muza SA, 2012), 253; Ewa Ferenc, Polskie tradycje świateczne (Poznań: Księgarnia św. Wojciecha, 2000), 86-87.

${ }^{22}$ Franciszek Jędrak, Zwyczaje, obrzedy $i$ wierzenia doroczne $w$ dekanacie gorzowskim (diecezja opolska) (Lublin: mps KUL, 2000), 256.

${ }^{23}$ Perszon, Zwyczaje, obrzędy i wierzenia doroczne, 98; tenże, Na Jastra, 12.

${ }^{24}$ Jan Perszon, Na brzegu życia i śmierci. Zwyczaje, obrzedy oraz wierzenia pogrzebowe $i$ zaduszkowe na Kaszubach (Lublin: Towarzystwo Naukowe KUL, 1999), 425. 
Synu Odkupicielu świata Boże, zmiłuj się nad nami.

Duchu Święty Boże, zmiłuj się nad nami.

Św. Trójco jedyny Boże, zmiłuj się nad nami.

Św. Józefie, najznakomitszy z Patryjarchów, zmiłuj się nad nami.

Św. Józefie, Ojcze, piastunie i karmicielu Dzieciątka Jezus, przyczyń się za nami.

Św. Józefie zaszczycony obecnością, towarzystwem Słowa wcielonego, przyczyń się za nami.

Św. Józefie, wodzu rodziny świętej, przyczyń się za nami.

Św. Józefie, wierny naśladowco Jezusa i Marji, przyczyń się za nami.

Św. Józefie, napełniony darami Ducha Świętego, przyczyń się za nami.

Św. Józefie, w czystości Aniołom wyrównający, przyczyń się za nami.

Św. Józefie, wzorze pokory i cierpliwości, przyczyń się za nami.

Św. Józefie, doskonały przykładzie życia wewnętrznego, przyczyń się za nami.

Św. Józefie, najwierniejszy wykonawco woli Ojca Najwyższego, przyczyń się za nami.

Św. Józefie, Oblubieńcze najczystszej z Dziewic, przyczyń się za nami.

Św. Józefie, któryś Syna Ojca Przedwiecznego na ręku niby na tronie nosił, przyczyń się za nami.

Św. Józefie, któryś z Jezusem i Marją dzielił trudy wygnania w Egipcie, przyczyń się za nami.

Św. Józefie, któryś z pociechą znalazł Jezusa w świątyni, przyczyń się za nami. Św. Józefie, któremu Król Chwały i Niebios Królowa posłuszną była, przyczyń się za nami.

Św. Józefie, przypuszczony do rozważania niezgłębionych tajemnic Boskich, przyczyń się za nami.

Św. Józefie, któryś miał szczęście oddać ducha na ręku Jezusa i Marji, przyczyń się za nami.

Św. Józefie, źródło niewyczerpane, z którego nam płyną łaski niebios, przyczyń się za nami.

Św. Józefie, potężna podporo Kościoła Chrystusowego, przyczyń się za nami.

Św. Józefie, najlepszy nasz patronie i Obrońco w godzinę śmierci, przyczyń się za nami.

Baranku Boży, który gładzisz grzechy świata - przepuść nam Panie!

Baranku Boży, który gładzisz grzechy świata - wysłuchaj nas Panie!

Baranku Boży, który gładzisz grzechy świata - zmiłuj się nad nami Panie!

Chryste usłysz nas, Chryste wysłuchaj nas.

Kyrie elejson, Chryste elejson, Kyrie elejson.

Jezu usłysz nas, Jezu wysłuchaj nas.

V. Módl się za nami święty Józefie,

R. Abyśmy się stali godnymi obietnic Pana Chrystusowych.

Módlmy się: Boże nieskończonego miłosierdzia, któryś wyniósł św. Józefa do niezrównanej godności Ojca i Opiekuna Twemu Boskiemu Synowi i Oblubieńca Najczystszej z Dziewic, przez przyczynę tak wielkiego świętego udziel nam Panie 
łaski, abyśmy serca nasze zachowali bez zmazy i godnymi byli kiedyś stawić się przed Tobą w szaty niewinności przyodziani i być przypuszczeni na gody Baranka na niebiosach. Przez Chrystusa Pana naszego. Amen ${ }^{25}$.

Pozdrowienie św. Józefa

Pozdrawiam Cię, święty Józefie

łaski Bożej pełen, Pan z Tobą, błogosławionyś

z pomiędzy mężów i błogosławiony Najczystszej

Oblubienicy Twojej Marji Owoc, Jezus.

Święty Józefie dzieciątka Jezus Piastunie,

Najświętszej Dziewicy Oblubieńcze, módl się za nami

Grzesznymi, teraz i w godzinę

śmierci naszej. Amen ${ }^{26}$.

Modlitwę do św. Józefa odmawiano przy codziennym pacierzu, a także podczas trzydniowych modlitw w domu zmarłego w oczekiwaniu na pogrzeb ${ }^{27}$.

W wierzeniach ludowych dzień św. Józefa uważany był jako graniczny między kończącą się zimą a rozpoczynającą wiosną, o czym mówi przysłowie: „Święty Józef - wiezie trawy wózek, ale czasem smuci - bo śniegiem porzuci”. Zwracano się do niego z wiarą, że przepędzi zimę: „Święty Józef kiwnie brodą, idźże zimo na dół z wodą”, w innej wersji: „Św. Józef skłoni brodą, zima idzie na dół z wodą”; „Na Józefa pięknie, zima prędko pęknie”, „Święty Józef Oblubieniec otwiera wiośnie gościniec”. Na Kaszubach mawiano: „św. Józef wiatrë, długą krekwią wegónio”, co oznaczało, że nastanie już ustabilizowana pogoda wiosenna ${ }^{28}$.

Tradycyjnie w całej Polsce w wigilię św. Józefa naprawiano bocianie gniazda w przekonaniu, że ptaki przylatujące z dalekich krajów przyniosą ze sobą wiosnę, szczęście i dostatek. Bociany były powszechnie szanowane przez mieszkańców wsi. Wierzono, że ich obecność na wiejskich strzechach przynosi domownikom szczęście. Do ich przybycia jako zwiastunów wiosny nawiązują przysłowia: „Na Józefa bociek przybędzie, śniegu już nie będzie”, „Na

\footnotetext{
${ }^{25}$ Zdzisław Kupisiński, Śmierć jako wydarzenie eschatyczne. Zwyczaje obrzedy i wierzenia pogrzebowe oraz zaduszkowe mieszkańców regionu opoczyńskiego i radomskiego (Lublin: Wydawnictwo KUL, 2007), 504-505.

${ }^{26}$ Tamże, 505.

27 Perszon, Na Jastra, 12; tenże, Jastrë na Helu. Wielki Post i okres wielkanocny na Pótwyspie Helskim (Lublin-Jastarnia: Urząd Miasta i Gminy Jastarnia, 1994), 28; tenże, Na brzegu życia i śmierci, 200-211; Kupisiński, Śmierć jako wydarzenie eschatyczne, 186-194.

${ }^{28}$ Oskar Kolberg, Mazowsze, cz. 1 (Dzieła wszystkie, t. 24) (Wrocław-Poznań: Ludowa Spółdzielnia Wydawnicza Polskie Wydawnictwo Muzyczne, 1963), 128; Stelmachowska, Rok obrzedowy na Pomorzu, 116; Perszon, Na Jastra, 13.
} 
Józefa bociek siądzie, mrozu więcej nie będzie”; „Gdy bociek na święty Józef przyleci, to na skrzydłach resztki śniegu przynosi” lub: „przynosi resztę śnieżnej zamieci" 29 .

Dzień św. Józefa był dla gospodarzy czasem rozpoczęcia wiosennych prac polowych. Na Kaszubach istniał zwyczaj, aby tego dnia przeorać chociażby jedna skibę ziemi, nawet wówczas, gdy na polu leżał jeszcze śnieg. Podobnie postępowano na ziemi chełmskiej. Orka nabierała wówczas znaczenia symbolicznego. Nawiązują do tego przysłowia: „Na świętego Józefa - przez pole bruzda”, albo „Święty Józef laską w ziemi kole, wyjeżdżajcie chłopcy orać w pole”30. Bożena Stelmachowska wspomina nawet o uprawie roli i zasiewach: „Na całym Pomorzu od Józefa rozpoczyna się orka, względnie siew, a w każdym razie przy pogodzie sprzyjającej należy pomyśleć o uprawie roli”31.

Stare przysłowia zachęcają, by w wigilię św. Józefa siać koniczynę, której nasiona uchodziły za „ziarno św. Józefa”. Według legendy święty podarował je chłopcu, który nie miał czym karmić inwentarza. W tym dniu wysiewano również groch, do czego nawiązywało przysłowie: „Uważajcie gospodarze, święty Józef groch siać każe”. Przystępując do prac na polu w święto św. Józefa, chciano zapewnić sobie obfite urodzaje i pomyślny początek wiosennych prac. Z kolei w centralnej Polsce istniało przekonanie, aby przed 19 marca siewu nie rozpoczynać, bowiem: „Przed Józefem siew - Pana Boga gniew, ale już od Józefa z owsa może być pociecha". Inne przysłowia posiadały konkretne rady, z których mogli skorzystać rolnicy, np.: „Jak na świętego Józefa chmurki, to sadź ziemniaki gdzie górki, a jak pogoda, to sadź gdzie woda"32.

Mieszkańcy wsi otaczali św. Józefa szczególną czcią, poświęcali mu wiele miejsca w modlitwach i pieśniach. Wizerunki świętego, ukazujące go z Jezusem na ręku lub przy warsztacie stolarskim i w obecności Maryi przy kądzieli były powszechne w izbach wiejskich. Uroczystość św. Józefa, przypadająca 19 marca, pokrywała się z czasem przygotowań do wiosennych prac polowych, dlatego wokół tegoż święta powstało wiele przysłów meteorologicznych i agrarnych.

${ }^{29}$ Zygmunt Gloger, Rok polski w życiu, tradycji i pieśni (Warszawa: Jan Fiszer, 1900), 135; Zaleski, Rok kościelny, 177.

${ }^{30}$ Gloger, Rok polski, 135; Stelmachowska, Rok obrzedowy na Pomorzu, 117.

${ }^{31}$ Stelmachowska, Rok obrzęowy na Pomorzu, 116; Perszon, Na Jastra, 12-13.

32 Krystyna Pawłowska, „Święty Józef w tradycji ludowej”, dostęp 04.02.2021, https:// www.przewodnik-katolicki.pl/Archiwum/2006/Przewodnik-Katolicki-12-2006/Diecezja-Wloclawska/Swiety-Jozef-w-tradycji-ludowej. 
Święty Józef - mąż Maryi, opiekun i wychowawca Jezusa, jest jednym z najważniejszych świętych Kościoła. Mieszkał w Nazarecie, był cieślą i stolarzem. Ewangelie przedstawiaja go jako człowieka pobożnego, pracowitego, pokornego. Na liturgiczny kult tego świętego wywarły wpływ zarówno przekazy ewangeliczne, jak i apokryfy związane z opisem lat dziecięcych Jezusa Chrystusa. Liturgiczne księgi wskazują, że przynajmniej od 1000 r. święto św. Józefa upowszechniło się na chrześcijańskim Wschodzie, a wiązano je ze zbawczymi tajemnicami (obchody świąt Bożego Narodzenia). Św. Józef stał się przedmiotem zainteresowania wielu teologów, już od średniowiecza: św. Piotr Damiani (†1072), św. Bernard z Clairvaux (†1153), św. Tomasz z Akwinu (†1274) i św. Albert Wielki (†1280). Również papieże zabierali głos odnośnie do tej postaci, począwszy od Piusa IX, który w 1870 r. ogłosił św. Józefa patronem Kościoła powszechnego, do Franciszka, który poświęcił świętemu Patriarsze list apostolski Patris Corde napisany z okazji 150. rocznicy ogłoszenia św. Józefa patronem Kościoła powszechnego oraz obrał go za patrona roku liturgicznego 2021.

W religijności i tradycji ludowej oddawano mu cześć głównie ze względu na fakt, że służył Jezusowi i Maryi, co przejawiało się w szerokiej pobożności i pochwałach pod jego adresem. Kult św. Józefa rozwijał się w pierwotnych formach folkloru, nabożeństwach, w skład których wchodziły: litanie, pieśni, modlitwy, w których celebruje się i rozważa tajemnice z życia św. Józefa. W pobożności ludowej nabożeństwa ku jego czci mają najczęściej charakter prywatny. Cześć oddawaną św. Józefowi można było dostrzec także w obrazach $\mathrm{z}$ jego wizerunkiem, umieszczanych $\mathrm{w}$ izbach wiejskich, figurach i kapliczkach przydrożnych, obierano go sobie za patrona (świątyń, miejscowości, stanów, zawodów, imion własnych). Obchody jego święta (19 marca) kojarzą się mieszkańcom wsi z okresem przełomowym, czasem zmieniających się pór roku, tj. kończącej się zimy i rozpoczynającej się wiosny, co zostało zobrazowane w licznych przysłowiach meteorologicznych, agrarnych, gospodarczych etc.

Widzimy, że postać św. Józefa rozważana w szerokim kontekście Ewangelii i jego autentyczny kult może przynieść wiele duchowych korzyści i to zarówno dla osób konsekrowanych, jak i świeckich. Jest on bowiem szczególnym nauczycielem uczestnictwa w mesjańskiej misji Chrystusa, która staje się w Kościele udziałem wszystkich wierzących. 


\section{BIBLIOGRAFIA}

Czerwiński, Tomasz. Kapliczki i krzyże przydrożne w Polsce. Warszawa: Sport i Turystyka Muza SA, 2012.

Ferenc, Ewa. Polskie tradycje świateczne. Poznań: Księgarnia św. Wojciecha, 2000.

Filas, Francis L. Święty Józef człowiek Jezusowi najbliższy. Tłum. Franciszek Dylewski. Kraków: Wydawnictwo WAM, 1979.

Fitych, Tadeusz. Trójca stworzona - nauka o św. Józefie na Ślasku. Lublin: Towarzystwo Naukowe KUL, 1990.

Franciszek, papież. „List apostolski papieża Franciszka Patris Corde z okazji 150. rocznicy ogłoszenia świętego Józefa patronem Kościoła powszechnego". Biuletyn Tygodniowy CIZ (14 grudnia) 50 (2020): 8-13.

Gloger, Zygmunt. Rok polski w życiu, tradycji i pieśni. Warszawa: Jan Fiszer, 1900.

Jędrak, Franciszek. Zwyczaje, obrzędy $i$ wierzenia doroczne $w$ dekanacie gorzowskim (diecezja opolska). Lublin: mps KUL, 2000.

Jodko, Rajmund. „Święci i błogosławieni w pobożności ludowej”. W Liturgia i pobożność ludowa, red. Władysław Nowak. 212-221. Olsztyn: Wydawnictwo Uniwersytetu WarmińskoMazurskiego, 2003.

Kolberg, Oskar. Mazowsze. Cz. 1 (Dzieła wszystkie, t. 24). Wrocław-Poznań: Ludowa Spółdzielnia Wydawnicza Polskie Wydawnictwo Muzyczne, 1963.

Kongregacja ds. Kultu Bożego i Dyscypliny Sakramentów. Dyrektorium o pobożności ludowej i liturgii. Zasady $i$ wskazania, red. bp Stefan Cichy. Poznań: Pallottinum, 2003.

Kupisiński, Zdzisław. Śmierć jako wydarzenie eschatyczne. Zwyczaje, obrzędy i wierzenia pogrzebowe oraz zaduszkowe mieszkańców regionu opoczyńskiego i radomskiego. Lublin: Wydawnictwo KUL, 2007.

Marlewski, Franciszek, red. Rok Boży w liturgii i tradycji Kościoła świętego z uwzględnieniem obrzędów i zwyczajów ludowych oraz literatury polskiej. Księga ku pouczeniu i zbudowaniu wiernych katolików. Katowice: Wydawnictwo św. Stanisława, 1931.

Nabożeństwa diecezji katowickiej. Agenda liturgiczna. Katowice: Księgarnia św. Jacka, 1995.

Nadolski, Bogusław. Liturgika. T. 2: Liturgia i czas. Poznań: Pallottinum, 1991.

Perszon, Jan. Jastrë na Helu. Wielki Post i okres wielkanocny na Pótwyspie Helskim. Lublin -Jastarnia: Urząd Miasta i Gminy Jastarnia, 1994.

Perszon, Jan. Na brzegu życia i śmierci. Zwyczaje, obrzedy oraz wierzenia pogrzebowe $i$ zaduszkowe na Kaszubach. Lublin: Towarzystwo Naukowe KUL, 1999.

Perszon, Jan. Na Jastra. Wielki Post i okres wielkanocny w Wejherowskiem. Luzino: Pektor, 1992.

Perszon, Jan. Zwyczaje, obrzedy i wierzenia doroczne $w$ regionie wejherowskim. Lublin: mps KUL, 1990.

Piszczek, Wacław CM. Wspomnienie świętych na każdy dzień. Martyrologium. Kraków: Wydawnictwo Instytutu Teologicznego Księży Misjonarzy, 2005.

Stelmachowska, Bożena. Rok obrzędowy na Pomorzu. Toruń: Wydawnictwo Instytutu Bałtyckiego, 1933.

Straszewicz, Marzena. „Józef Oblubieniec, II. Kult”. W Encyklopedia katolicka, red. Bogusław Migut i inni. T. 8, 125-127. Lublin: Towarzystwo Naukowe KUL, 2000.

Szymik, Stefan. „Józef Oblubieniec, I. Życie”. W Encyklopedia katolicka, red. Bogusław Migut i in. T. 8, 124-125. Lublin: Towarzystwo Naukowe KUL, 2000.

Świtała-Trybek, Dorota. Święta i zabawa. Odpusty parafialne na Górnym Ślasku. Wrocław: Polskie Towarzystwo Ludoznawcze, 2000. 
Zaleski, Wincenty. Rok kościelny. Święta Pańskie, Matki Bożej, Apostołów, Świętych i Błogostawionych Pańskich oraz dni okolicznościowe. Warszawa: Wydawnictwo Salezjańskie, 1989.

Strony internetowe

Kalinowski, Zenon. „Święta Rodzina”. Nasza Rodzina nr 5 (320) (1971): 10-11. Dostęp 01.02. 2021. http://recogito.eu/swieta-rodzina/.

Pawłowska, Krystyna. „Święty Józef w tradycji ludowej”. Dostęp 04.02.2021. https://www. przewodnik-katolicki.pl/Archiwum/2006/Przewodnik-Katolicki-12-2006/Diecezja-Wloclawska/Swiety-Jozef-w-tradycji-ludowej.

Plota, Jacek. „Sanktuarium św. Józefa w Kaliszu”. Dostęp 02.02.2021. http://www.radoslaw. home.pl/sanktuaria/kalisz.htm.

\title{
ŚWIĘTY JÓZEF W RELIGIJNOŚCI I TRADYCJI LUDOWEJ W POLSCE
}

\author{
St re s z c z e n i e
}

Cześć oddawana świętym jest w swej istocie kultem Jedynego Boga i uwielbieniem go w dziełach, które uczynił w swoich świętych. Jest również formą wyrażenia wdzięczności Bogu za to, że pozwala ludziom na udział w swej świętości i doprowadza swoich wybranych do chwały nieba. Jednym ze świętych cieszących się szczególną czcią w Kościele jest św. Józef - mąż Maryi i opiekun Jezusa. W artykule autor stawia sobie za cel prezentację tej postaci na podstawie przekazów ewangelicznych, dokonuje także charakterystyki rozwoju kultu św. Józefa w Kościele oraz w religijności i tradycji ludowej. Do opracowania tematu skorzystał z literatury teologicznej, etnologicznej oraz własnych etnograficznych badań terenowych prowadzonych w subregionie opoczyńskim i radomskim (centralna Polska).

Kult św. Józefa dostrzega się nie tylko w liturgii Kościoła, gdzie jego główne święta obchodzone są 19 marca i 1 maja, ale także w religijności ludowej. Cześć oddawana temu świętemu przejawia się w nabożeństwach ku jego czci, pieśniach, modlitwach, w licznych obrazach z jego wizerunkiem umieszczanych w domach oraz przydrożnych kapliczkach. Św. Józef wielokrotnie obierany jest za patrona kościołów, miejscowości, zawodów, uznawany jest także za opiekuna ojców oraz patrona dobrej śmierci. Jego kult jest żywy również w czasach współczesnych, a przez wstawiennictwo tegoż świętego u Boga wiele osób otrzymuje wypraszane łaski.

Słowa kluczowe: św. Józef; kult; pobożność; religijność ludowa; tradycja. 